Zagadnienia Rodzajów Literackich, LX, z. 3

PL ISSN 0084-4446

DOI: $10.26485 / Z R L / 2017 / 60.3 / 9$

Anna Smywińska-PoHL

ANNA JARMUSZKIEWICZ

Uniwersytet Jagielloński,

Polska Akademia Umiejętności**

Polska Akademia Umiejętności*

\title{
Dzieła osierocone jako wyzwanie dla humanistyki
}

\author{
Orphan Works as a Challenge for Humanities
}

\begin{abstract}
The article presents the legal concept of orphan works in the context of the Polish Law on Copyright and its social and cultural impact on the effectiveness of scientific research, especially in the field of humanities. The purpose of introducing legislative solutions relating to orphan works is to save the cultural heritage from oblivion, and also to restore the continuity of scientific research. The article also raises the question of the contemporary idea of Open Access, which is considered as another plane for new humanities - as a place of common ground to exchange knowledge without barriers.
\end{abstract}


* Polska Akademia Umiejętności w Krakowie Instytut Judaistyki Uniwersytetu Jagiellońskiego adres do korespondencji: ul. Librowszczyzna 7/8, 31-030 Kraków e-mail: ansmpo@gmail.com

** Polska Akademia Umiejętności w Krakowie adres do korespondencji: ul. Bartycka 115/5, 00-716 Warszawa e-mail: jarmuszkiewicz.a@gmail.com

Artykuł został sfinansowany ze środków Narodowego Centrum Nauki na podstawie umowy nr UMO-2014/13/N/HS2/02813. 
Celem niniejszego artykułu jest próba określenia miejsca i znaczenia kategorii utworów osieroconych we współczesnej humanistyce. Problem utworów, których autor jest niemożliwy do odnalezienia, jego losy pozostają nieznane (np. data śmierci) bądź nie ma z nim kontaktu, co pozwoliłoby na np. ponowne upublicznienie dzieła, nie jest zagadnieniem z gruntu nowym. Zapewne pojawiło się ono wraz z ukonstytuowaniem się nowoczesnego myślenia o prawach autorskich (a więc już w wieku XIX). Jednak to, co uległo w ostatnich dekadach znaczacej zmianie, to fakt, że rozwinęła się refleksja nad utworami osieroconymi — nie tylko o charakterze prawnym, lecz także — co warto podkreślić — zaczęto zauważać zjawisko jako specyficzny wymiar społeczno-kulturowy współczesności.

Problemy badawcze, które chcemy rozwinąć w artykule, dotyczą określenia sposobów korzystania z utworów osieroconych oraz wykazania silnych i słabszych stron nowowprowadzonych regulacji prawnych w tym zakresie. Jednak w większym stopniu interesuje nas kwestia ciagłości nauki w świetle gromadzenia oraz dostępu do dorobku poprzedników. $\mathrm{Z}$ tego samego powodu zasadne wydaje się zestawienie problemu utworów osieroconych z koncepcja open access — zawarte w ostatniej części artykułu.

\section{Problemy w ustalaniu stanu badań w różnych dziedzinach nauki}

Cyceron w dialogu $O$ mówcy pisze słynne słowa, że historia jest nauczycielką życia (Pajestka 1991: 191). Niestety, rzadko zdarza się, abyśmy mieli dostęp do przeszłych zdarzeń poprzez poznanie pełnej dokumentacji, a także — wielości narracji i perspektyw. Rzadziej jeszcze mamy świadomość tego, w jaki sposób historia jest budowana, z jak „,niewielkich skrawków źródeł jest zszywana” i jaką rolę odgrywa polityka historyczna. Zajmując się historia, ale też i każdą inną dziedzina, w sposób naukowy, zobligowani jesteśmy do sprawdzenia, jaki jest stan badań w danym zakresie, jakie ustalenia poczynili nasi poprzednicy. Niekiedy stwierdzenie, w jakim momencie kreowana jest dana idea, staje się tak utrudnione, że nawet wręcz niemożliwe. Dzieje się tak z kilku względów: ogromnych nakładów pracy, aby określić pierwszego autora podejmującego dane zagadnienie, problemach w dostępie do źródeł lub po prostu ich zniszczeniu. Świadomość tych ograniczeń pozwala przyjmować szerszą perspektywę badawczą i przedstawiać mniej subiektywną wersję historii. 
O ile w naukach ścisłych i przyrodniczych naukowcy zwykle odnoszą się do najnowszych wyników badań, nie sięgając do idei, ale je kontynuując, o tyle inaczej rzecz ma się w szeroko rozumianej humanistyce. W naukach ścisłych badania mają raczej charakter rozbudowujący daną dziedzinę, a w humanistyce — pogłębienia wiedzy w obrębie kwestii; badania mają charakter podstawowy, a te same procesy myślowe przeprowadza się wielokrotnie. Z tej też przyczyny w naukach humanistycznych badanie stanu wiedzy w danej dziedzinie winno być bardziej nasilone.

Niedostatek informacji sprawia, że nie tylko nie mamy pełnego obrazu badań, ale także umyka nam orientacja o sposobie powstawania nowych koncepcji czy nawet relacje migracji wiedzy między badaczami i badaczkami. Dobrą ilustracją mogą być tutaj przedwojenne i powojenne prace doktorskie oraz magisterskie z Wydziału Filozoficznego na Uniwersytecie Jagiellońskim. Pierwszą kobieta, która otrzymała dyplom doktorski w zakresie filozofii ścisłej, była Stefania Tatarówna ${ }^{1}$. W 1906 roku nadano jej stopień po napisaniu pracy Król-duch Stowackiego a nadczłowiek. Nietzschego. Dysertacja ta została opracowana wkrótce po śmierci niemieckiego filozofa, jednak do tego czasu wiele prac na temat jego dorobku powstało na ziemiach polskich (co ciekawe, Nietzsche był przez przeważającą część badaczy traktowany wówczas jako literat a nie filozof). Doktorat Stefanii Tatarówny należy do niewielu spośród tych, które zachowały się w Archiwum Uniwersytetu Jagiellońskiego (zob. Archiwum Uniwersytetu Jagiellońskiego), ponadto został w całości opublikowany na łamach „Pamiętnika Literackiego” w 1906 roku (Tatarówna 1906a,b). Próżno jednak w tej pracy szukać bibliografii, dowiadujemy się z niej niemniej, że filozofka samodzielnie tłumaczyła Nietzschego. W tych latach powstało jednakże wiele tekstów na temat Nietzschego, np. opracowanie Zofii Daszyńskiej-Golińskiej² czy Maurycego Straszewskiego ${ }^{3}$, recenzenta Stefanii, który w pracy o Nietzschem również pominął kwestię poprzednich badaczy ${ }^{4}$. Powoduje to, że z czasem podczas rozważań naukowych umykają refleksje poprzedników, które mogłyby znacząco wzbogacić kolejne prace. Wraz z niszczeniem nośników materialnych giną też pewne idee, co zubaża całą humanistykę.

Podobna sytuacja miała miejsce w odniesieniu do prac dotyczacych Johna Stuarta Milla. Niemal w tym samym czasie powstały doktoraty: Haliny Biegańskiej-Płodowskiej — Zagadnienie prayczynowości u Milla (1908), praca recenzowana ${ }^{5}$ przez Stefana

1 Stefania Tatarówna (1880-1942) — filozofka, nauczycielka, poetka, członkini Polskiego Towarzystwa Filozoficznego we Lwowie (od 1907), Związku Literatów Polskich, założycielka Stowarzyszenia Kobiet z Wyższym Wykształceniem, nauczycielka, poetka i pisarka. Opublikowała między innymi Poezje Buddha (1903), poemat Za Stońce (1908), O mitości mistrza Twardowskiego historia smutna i inne nowele (1926), Porachunek z szatanem (1928), Przeciw losowi (1930), Moralne podstawy ideologii polskiej (1937), Legenda i prawda o matce (1939).

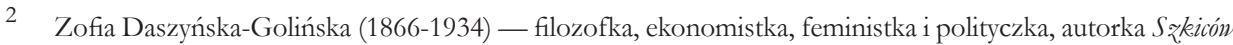
metodologicznych i Polityki społecænej. W 1896 wydała w Krakowie publikację Nietzssche-Zaratrusta — studium literackie.

3 Maurycy Straszewski (1848-1921) — profesor Uniwersytetu Jagiellońskiego i Katolickiego Uniwersytetu Lubelskiego, promował filozofię otwartą na kwestie naukowe i przyrodnicze, założyciel Towarzystwa Filozoficznego w Krakowie.

4 Odnoszę się tutaj do tekstu Fryderyk Nietzsche i jego znnaczenie w ruchu umysłonym współcæesnym, który ukazał się na łamach Przewodnika Naukowego i Literackiego (1906, r. 34, s. 614-629). W 2013 roku tekst ponownie ukazał się na łamach Kronosu (4/2013). Straszewski w swej pracy, tak jak Tatarówna, również nie podał żadnej bibliografii.

5 Prace pisane były wówczas samodzielnie, bez oficjalnego promotora. Opiekunem naukowym był zwykle jeden z recenzentów, promotorem nazywano osobę, która wręczała dyplom podczas promocji doktorskiej. 
Pawlickiego ${ }^{6}$ i Maurycego Straszewskiego, oraz Ludwika Zengtellera — Poglady Johna Stuarta Milla na prajyczynowość. Po wojnie tą tematyką zajęły się między innymi Halina Poświatowska ${ }^{7}$ oraz Janina Makota ${ }^{8}$. W wymienionych pracach brak widocznej łączności pokoleniowej i świadomości tego, że wcześniej prowadzono bardzo podobne badania. Być może było to spowodowane właśnie brakiem dostępu do tych tekstów, a także do ówczesnej kadry — z przedwojennych profesorów filozofii na UJ, po roku 1945, aktywny naukowo był właściwie tylko Władysław Heinrich?

\section{Dzieła osierocone jako problem nie tylko prawnoautorski}

Obecnie, poza wspomnianymi problemami — a więc brakiem informacji o prekursorach, a także kwestią zachowania źródeł, zwłaszcza w postaci rozpraw, istotna dla wykorzystania prac poprzedników jest ochrona praw twórców na gruncie prawa autorskiego. O ile współcześnie studenci piszący prace magisterskie podpisują deklaracje dotyczące zgody na dostęp do ich prac, o tyle wcześniej takie kwestie nie były uregulowane. Pojawia się więc pytanie, czy możemy domniemywać, iż autorzy prac nie mieliby nic przeciwko ich udostępnianiu. Niekiedy istnieje możliwość nawiązania kontaktu z twórcą i zapytania o zgodę, często jest to jednak niemożliwe, ponieważ nie ma informacji na temat jego losów, nie wiadomo też, czy żyje, gdzie przebywa itd. Tego typu sytuacje zdarzają się przede wszystkim w związku z pracami przedwojennymi, których autorami w dużej mierze były osoby pochodzenia żydowskiego. W okresie międzywojennym na Uniwersytecie Jagiellońskim na Wydziale Filozoficznym Żydzi stanowili ponad 45\% ogółu studentów (Kulczykowski 2004: 76). Ogromna część z nich zginęła bądź zaginęła w czasie wojny i nie mamy w pełni legalnego dostępu do ich dziedzictwa. Takie utwory nazywają się „osieroconymi”.

Wedle różnych danych dzieła osierocone stanowią nawet 65\% ogółu prac znajdujących się w bibliotekach i archiwach. Bez dostępu do nich znacząco ograniczamy rozwój nauki, jak i tracimy dziedzictwo kulturowe — nie tylko dlatego, że obecnie jest ono niedostępne, ale także dlatego, że źródła, a zwłaszcza papier, mają ograniczoną żywotność z czasem niszczeją, kruszą się i są bezpowrotnie tracone. Nie podejmując odpowiednich działań, wykluczamy na zawsze pewne dyskursy i narracje. Okres trwania praw autorskich był systematycznie przedłużany i obecnie wynosi siedemdziesiąt lat od śmierci twórcy lub ostatniego ze współtwórców. Tak długi czas trwania ochrony powoduje trudności

6 Stefan Pawlicki (1839-1916), ksiądz, filozof i historyk filozofii, rektor Uniwersytetu Jagiellońskiego w latach 1905-1906, prowadził wykłady na temat filozofii F. Nietzschego.

7 Halina Poświatowska (1935-1967) — pisarka, poetka i filozofka. Promotorem jej pracy magisterskiej Praycaynowości w Systemie Logiki Johna Stuarta Milla był Roman Ingarden. Praca się zachowała, a jej fragmenty zostały opublikowane w Filozofkeach na Uniwersytecie Jagiellońskim 1897-1967 pod red. E. Chudoby, A. Smywińskiej-Pohl (WUJ, Kraków 2016). Poświatowska była zatrudniona w Zakładzie Filozofii Przyrody UJ. Pracę doktorską Etyçne zasady Martina Luthera Kinga w jego pismach i działalności antyrasistowskiej przygotowywała pod opieką Marii Ossowskiej.

8 Janina Makota (1921-2010) — filolożka angielska, filozofka i poetka. Jej praca magisterska na anglistyce była zatytułowana An Aesthetic Investiagation of William Blake's Poetry and Painting. Pracę doktorską z filozofii poświęciła kwestiom estetycznym — Klasyfikacja sұtuk pięknych i wrajemne między nimi stosunki, a jednym z jej recenzentów był Władysław Tatarkiewicz.

9 Władysław Heinrich (1869-1957) — filozof i psycholog, założył pierwsze na ziemiach polskich laboratorium psychologii eksperymentalnej, które było bardzo nowocześnie wyposażone, po wojnie skłonił się ku zagadnieniom pedagogicznym 
w odnalezieniu spadkobierców i w rzeczywistości sprawia, że ochrona ta trwa dłużej (Szczepańska 2008).

Warto przypomnieć genezę powstania pojęcia utworów osieroconych na polskim gruncie prawnym. Jak podkreśla polski prawodawca w uzasadnieniu do tzw. dużej nowelizacji ustawy o prawie autorskim i prawach pokrewnych:

(...) w zbiorach polskich instytucji kultury, także ze względu na burzliwe wydarzenia polskiej historii ostatnich kilkudziesięciu lat, znajduje się znaczna liczba dzieł osieroconych o różnym charakterze: literackich (książki, czasopisma), plastycznych (np. plakaty), fotograficznych (zdjęcia, pocztówki), muzycznych czy audiowizualnych. Tylko w zbiorach Biblioteki Narodowej ${ }^{10}$ znajduje się ok. 300 tys. jednostek bibliotecznych, które są dziełami osieroconymi (dotyczy to np. znacznej części dorobku polskiej prasy podziemnej z czasu II wojny światowej oraz okresu PRL). W zbiorach Filmoteki Narodowej jest ok. 300 filmów będących dziełami osieroconymi o charakterze fabularnym, dokumentalnym czy krótkometrażowym (np. dotyczy to całego dorobku polskiej kinematografii w okresie międzywojennym, w tym filmów w języku jidysz). Wiele utworów osieroconych znajduje się także w archiwach nadawców publicznych.

(Druk sejmowy nr 3449. Uzasadnienie 2015: II.3.1.1)

Uregulowanie statusu dzieł niedostępnych w obrocie handlowym — z pełnym poszanowaniem praw uprawnionych - ułatwiłoby obywatelom dostęp przede wszystkim do książek i czasopism często o istotnej wartości historycznej, artystycznej i informacyjnej, których eksploatacja, z jednej strony nie budzi obecnie zainteresowania podmiotów działających na rynku, a z drugiej zaś nie wywołuje sprzeciwu uprawnionych. (Druk sejmowy nr 3449. Uzasadnienie 2015: I)

Agnieszka Vetulani-Cęgiel podkreśla również bardzo praktyczny aspekt konieczności „uwolnienia” dzieł osieroconych:

W ramach inicjatywy tworzenia europejskich bibliotek cyfrowych instytucje kultury, takie jak biblioteki, archiwa, mediateki, muzea itp., zwróciły uwagę na trudności związane z eksploatacja tzw. dzieł osieroconych. Problem polegał na chęci digitalizacji dzieła i dalej jego udostępniania online, na co — zasadniczo — wymagana jest zgoda podmiotu uprawnionego. (...) Problemy dotyczyły w szczególności dzieł starszych ze względu na trudności w dotarciu do właściwych umów lub brak informacji na temat przeniesienia praw z powodów historycznych (np. zmiany granic, ustroju lub prawa, bankructwo lub fuzja przedsiębiorstw). (Vetulani-Cięgiel 2013: 15) ${ }^{11}$

Innymi problemami, o których wspominały te instytucje, były wysokie koszty prowadzenia poszukiwań podmiotów uprawnionych w celu ustalenia, czy nadal korzystają z ochrony prawa autorskiego oraz ewentualnego zweryfikowania — zidentyfikowania podmiotu uprawnionego.

10 Warto przybliżyć również inne dane na ten temat:

British Library podaje, że ponad $40 \%$ utworów chronionych prawem autorskim to utwory osierocone. (...) Ze sprawozdania In from the Cold można było się dowiedzieć, że około $90 \%$ archiwów fotograficznych w instytucjach kultury Wielkiej Brytanii to (...) dzieła osierocone. (Vetulani-Cięgiel 2013: 16).

11 Warto podkreślić, że utwór osierocony może być wykorzystywany w ramach dozwolonego użytku prywatnego i publicznego zgodnie z art. 23-35 ustawy o prawie autorskim i prawach pokrewnych z 4 lutego 1994 r. 


\section{Rozwiązania prawne dotyczące dzieł osieroconych}

Parlament Europejski dostrzegł problem dzieł osieroconych. W 2012 roku została uchwalona dyrektywa w sprawie niektórych dozwolonych sposobów korzystania z utworów osieroconych. Ustawodawca starał się zważyć interesy autorów, a także zakres prawa społeczeństwa do kultury. W dyrektywie zwrócono uwagę na postępujący proces digitalizacji zabiorów instytucji kultury, co przyczynia się do ochrony europejskiego dziedzictwa, z drugiej zaś strony rodzi problemy natury prawnej związanej właśnie z prawami autorskimi. Dzieła osierocone zostały zdefiniowane jako takie utwory, które prawdopodobnie objęte są prawem autorskim, ale nie są znane osoby uprawnione do zarządzania utworem, a nawet jeśli są znane, nie jest możliwe skontaktowanie się z nimi, pomimo przeprowadzenia procesu starannego poszukiwania. Prawodawca zezwala na korzystanie z dzieł osieroconych, ale z licznymi ograniczeniami. Dotyczą one przede wszystkim tego, że dzieła osierocone mogą być udostępniane przez instytucje publiczne, takie jak archiwa, biblioteki, muzea czy placówki oświatowe, jednak nie w sposób komercyjny. Nie oznacza to bynajmniej, że udostępnienie takie jest nieodpłatne — instytucja może pobrać opłatę będąca zwrotem za nakład pracy, ale dzieła osierocone nie mogą służyć czerpaniu zysków. Po przeprowadzeniu procesu starannego wyszukiwania instytucja będąca w posiadaniu utworu może go digitalizować, zwielokrotniać i udostępniać odbiorcom droga elektroniczna. Jednym z poważniejszych zarzutów względem dyrektywy jest podjęcie w niej problemu tylko wybranych rodzajów utworów. Na gruncie prawa autorskiego nie wytyczono minimalnego progu twórczości, który uprawniałby dany wytwór człowieka do otrzymania miana utworu. Z tych względów ochrona przysługuje także przepisom kulinarnym, rozkładom jazdy czy zdjęciom jedzenia. Powoduje to, że utworów mamy bardzo wiele i wiele jest też ich rodzajów. Tymczasem Parlament Europejski i Rada podejmując temat sieroctwa dzieł, ograniczył się do ustaleń tylko do kilku ich rodzajów - dzieł piśmienniczych, fonogramów, wideogramów. Michał Błeszyński wskazuje na braki w takim rozwiązaniu i przesunięcie rozwikłania problemu pozostałych rodzajów dzieł na ustawodawców krajowych (Błeszyński 2013). Wyszukiwanie winno być przeprowadzone w dobrej wierze i obejmować (w przypadku piśmiennictwa) sprawdzenie w instytucjach takich jak biblioteki, archiwa, stowarzyszenia autorów i wydawców, bazy ISBN/ISSN i inne.

Kraje członkowskie Unii Europejskiej miały wprowadzić zmiany w krajowych przepisach dotyczących prawa autorskiego do 29 października 2014 roku. Polska zaimplementowała zmiany w prawie autorskim w 2015 roku $^{12}$. W październiku 2015 roku zostało wydane rozporządzenie Ministerstwa Kultury i Dziedzictwa Narodowego w sprawie procesu starannego wyszukiwania właściciela praw majątkowych ${ }^{13}$. W przypadku utworów literackich w formie książkowej należy przeprowadzić kwerendy w następujących miejscach:

- bazach Biblioteki Narodowej i Biblioteki Jagiellońskiej, bibliotek regionalnych i specjalistycznych, jeśli dana tematyka ich dotyczy;

\footnotetext{
12 Mowa tutaj o ustawie z 11 września 2015 r. o zmianie ustawy o prawie autorskim i prawach pokrewnych oraz ustawy o grach hazardowych, która weszła w życie 19 listopada 2015 roku.

Mowa tutaj o Rozporządzeniu Ministra Kultury i Dziedzictwa Narodowego z 23 października 2015 r. w sprawie wykazu źródeł, których sprawdzenie jest wymagane w ramach starannych poszukiwań uprawnionych do utworów i przedmiotów praw pokrewnych, które mogą być uznane za osierocone, oraz sposobu dokumentowania informacji o wynikach starannych poszukiwań Dz. U. poz. 1258.
} 
- w stowarzyszeniach twórców i wydawców: Polskiej Izbie Książki, Stowarzyszeniu Pisarzy Polskich, Związku Literatów Polskich, Polskim PEN Clubie;

- rejestrach i bazach publikacji drukowanych: WATCH, ISBN (prowadzona przez Bibliotekę Narodowa), VIAF i ARROW.

Należy sprawdzić także bazy organizacji zbiorowego zarządzania: Stowarzyszenia Autorów ZAiKS, Stowarzyszenia Autorów i Wydawców Copyright Polska, Stowarzyszenia Zbiorowego Zarządzania Prawami Autorskimi Twórców Dzieł Naukowych i Technicznych KOPIPOL; oraz bazę wydawcy danej publikacji, o ile nadal istnieje.

W przypadku czasopism wymogi są zbliżone. Po przeszukaniu dostępnych baz danych i w wypadku nieodnalezienia właściciela praw majatkowych (proces wyszukiwania właściciela praw majątkowych jest dokumentowany w wersji elektronicznej) biblioteka, archiwum bądź inna uprawniona instytucja, wpisuje dany utwór do bazy dzieł osieroconych, która jest wspólna dla całej Unii Europejskiej (baza Urzędu Unii Europejskiej ds. Własności Intelektualnej — EUIPO $\left.{ }^{14}\right)$. Niestety, na chwilę obecną ze strony Polski nie został zgłoszony do bazy żaden utwór osierocony. Najwięcej utworów osieroconych zgłoszono z Wielkiej Brytanii (40\%), Węgier (25\%) i Holandii (25\%). Zapewne znaczenie odgrywa tutaj fakt, iż w Holandii i na Węrrzech istniały rozwiązania dotyczące dzieł osieroconych jeszcze przed wejściem w życie dyrektywy (ale odpowiednie regulacje były także w Danii i Francji).

Proces starannego wyszukiwania jest praco- i czasochłonny, a ponadto nie jest pozbawiony wad. W przypadku niektórych baz przeszukiwanie ich celem znalezienia informacji o autorze lub jego spadkobiercach jest bezcelowe, bowiem powstały one później niż utwory (tak dzieje się chociażby w przypadku baz ISBN — utwory powstałe do połowy lat 70. XX wieku nie posiadają tego numeru), podobnie ma się rzecz ze stowarzyszeniami twórców. Założone przez ustawodawcę kryteria okazują się niewystarczające, w wyniku czego archiwa i biblioteki albo rezygnuja z digitalizacji takich utworów, albo prowadza własne poszukiwania, które obejmują inne niż wymienione w przytoczonym rozporządzeniu osoby i instytucje. Przede wszystkim skupiają się na Urzędach Stanu Cywilnego (obecnie trwa digitalizacja wszystkich aktów stanu cywilnego, istnieje więc szansa, że łatwiej będzie można przesuwać utwory do domeny publicznej), a także na kontakcie z osobami, które były współpracownikami bądź uczniami autorów — starają się uzyskać informacje o spadkobiercach i właścicielach praw majątkowych w sposób nieoficjalny. Wydaje się, że sposób stosowany przez biblioteki i archiwa może być skuteczniejszy. Na przykład podczas wykonywania kwerendy dotyczącej dzieł napisanych przez filozofów i polonistów pochodzenia żydowskiego związanych z Uniwersytetem Jagiellońskim żadna z wymienionych $\mathrm{w}$ dokumencie rządowym organizacji nie była w posiadaniu informacji na temat interesujących autorki dzieł i autorów. Tymczasem pogłębiona kwerenda — zapytania w Instytucie Pamięci Narodowej i Urzędzie Stanu Cywilnego — przyniosła rezultaty.

Drugim problemem jest przeprowadzanie całego procesu dla każdego utworu oddzielnie. Wydaje się, że znaczącym ułatwieniem mogłoby być (przynajmniej w niektórych przypadkach) wykazanie listy autorów, co do których spadkobiercy (bądź inni właściciele praw majątkowych) nie są znani. Tymczasem przynajmniej część instytucji, zwłaszcza

14 Baza utworów osieroconych znajduje się pod adresem https://euipo.europa.eu/orphanworks/. 
stowarzyszeń, posiada właśnie listy osobowe. Jeśli dana organizacja nie posiada informacji na temat danego autora, zbędnym wydaje się uzyskiwanie takiego potwierdzenia dla każdego utworu.

\section{Stan zachowania źródeł a dzieła osierocone}

Podczas analizy kwestii związanych z dziedzictwem kulturowym Żydów jednym z kluczowych problemów jest zachowanie źródeł. Niestety, jeśli chodzi o filozofów i polonistów związanych z UJ w dwudziestoleciu międzywojennym, zachował się tylko niewielki procent prac. W latach 1918-1939 na Uniwersytecie Jagiellońskim wydano siedemdziesiąt osiem dyplomów doktorskich z zakresu filozofii ścisłej, tymczasem zachowało się jedynie czternaście prac (18\%). Podobny odsetek dysertacji zachował się także w innych dyscyplinach. W przypadku większości z nich nie są znane losy autorów w czasie wojny i po niejnie wiadomo więc, czy utwory te mogłyby trafić do domeny publicznej lub czy powinny zyskać status dzieł osieroconych. Świadomość braku źródeł powinna wybrzmieć podczas badań nad wkładem uczonych do rozwoju nauki, a także przy badaniu historii nauki niestety dostępne nam źródła nie pozwalają na pełną ocenę ich dokonań z tego okresu.

\section{Open access a utwory osierocone wobec wyzwań humanistyki}

Warto również ukazać problem wyzwań humanistyki przez pryzmat koncepcji open access, jednocześnie przybliżając i to pojęcie. Obrazuje to nowe perspektywy humanistyki posiadającej dostęp do zamkniętych dotychczas źródeł — tym samym humanistyki o pełniejszym wymiarze, unikającej wyważania otwartych drzwi. Aby opisać te zagadnienia, trzeba zaczać od szerszego zarysowania problemu, jakim jest kwestia zapisu i utrwalenia dorobku intelektualnego.

Posługując się szeregiem (niezbędnych dla niniejszego artykułu) uproszczeń, można powiedzieć, że od momentu powstania pisma i swoistego regresu kultury oralnej humanistyka opiera się na słowie pisanym. Co za tym idzie — myśl humanistyczna jest zmaterializowana w postaci utworu - to właśnie zapis, w kontraście do ulotności słowa mówionego, daje szansę na ciagłość i komplementarność emanacji ludzkiego umysłu, a tym samym ciągłość pokoleniową i agregację dorobku.

Twierdzenia te nie są odosobnione. Znajdują refleks w wielu miejscach, co ilustruje na przykład współczesne zaproszenie konferencyjne „Kultura książki w humanistyce współczesnej” z okazji 60-lecia Instytutu Informacji Naukowej i Bibliotekoznawstwa Uniwersytetu Wrocławskiego:

Współczesna humanistyka opiera się na książce, a jednocześnie coraz mocniej w badaniach naukowych podkreśla się zmieniającą rolę książki w kulturze. Książka stała się nie tylko przedmiotem materialnym i nośnikiem różnorodnych treści pełniących wiele funkcji, ale przede wszystkim jako pierwsze medium odgrywa istotną rolę w procesie komunikacji społecznej, stając się narzędziem utrwalania i przekazywania myśli ludzkiej. (...) Światowe dziedzictwo książkowe jest składnikiem kultury, a pojęcia „kultura książki” i „humanistyka” są ze sobą ściśle powiązane. Im bardziej nowoczesny staje się świat, tym większa potrzeba badań w obszarze humanistyki, łączącej zarówno twórców, jak i odbiorców szeroko pojętej kultury. Współcześnie humanistyka cyfrowa staje się fundamentem utrwalającym dorobek umysłowy ludzkości oraz narzędziem transmisji pamięci kulturowej, w której zasadniczą rolę odgrywa książka.

(Instytut Informacji Naukowej i Bibliotekoznawstwa Uniwersytetu Wrocławskiego 2016) 
Przywołany wyżej fragment jest przykładem sądu, że nawet w dość potocznej opinii ${ }^{15}$ humanistyka jest niejako utożsamiana z książką (tekstem) jako wyrazem (zapisem) dorobku umysłowego danej kultury i staje się ona ważnym elementem komunikacji społecznej. Podkreślona zostaje potrzeba utrwalenia, przekazywania wiedzy na odległość oraz w czasie (dla następców). Kolejnym jej celem jest „transmisja pamięci kulturowej”, która jednak nie zawsze przebiega w sposób ciagły i niepozbawiony wyrw. Niejednokrotnie komunikacja między pokoleniami może zostać przerwana — niektóre utwory wypadają z obiegu i moga przestać cyrkulować w świadomości społecznej. Może je spotkać sytuacja przemieszczenia w strukturze kanonu i pamięci kulturowej, którą badacz literatury światowej David Damrosch podzielił na trzy poziomy: hiperkanon, antykanon i kanon cieni. Tylko niektóre dzieła zapewniają sobie trwałe miejsce w ,wąskim towarzystwie” ponadczasowych arcydzieł Damrosch nazywa je zbiorczo hiperkanonem. Jak pisano już w innym opracowaniu (por. Jarmuszkiewicz 2012), większość utworów może jednak krążyć tak przez lata, pomimo że często mają nawet status wielkiego dzieła. Pozostałe, niższe poziomy tego „kanonu” to antykanon i kanon cieni. $\mathrm{Na}$ antykanon składają się utwory niepierwszorzędnych, często kontestacyjnych pisarzy, którzy pisali „w językach nienauczanych powszechnie lub w językach wielkich mocarstw, ale w obrębie mniejszych literatur" (Damrosch 2010: 370-371). Z kolei kanon cieni jest tworzony przez wszystkich pomniejszych autorów, którzy z czasem wypadają z systemu literackiego, opuszczając pamięć kulturowa.

Przyczyny przerwania łańcucha odbiorców moga być różnorakie. Mają charakter ograniczeń prawnych związanych z regulacjami prawa autorskiego, np. cenzura. Częstym powodem jest także brak materialnego dostępu do tekstu z powodu wykluczenia ekonomicznego (wysoka cena) oraz materialny rozpad nośników utworu, a także — i niestety konsekwencje działania siły wyższej: kataklizmu, wojny, zmiany granic państwa. Należy jednak pamiętać, że „łańcuch odbiorców” może jednak, choć częściowo, zostać złączony dzięki zabiegom o charakterze prawnym, takim jak np. nieodpłatne udostępnienie tekstów naukowych (open access), które przyczyni się do ich upowszechnienia w świecie nauki. Kolejnym uzupełniającym elementem jest wprowadzenie do obiegu prawnego instytucji dzieła osieroconego wraz z całym szeregiem towarzyszących mu zasad korzystania. Dzięki zwiększonemu dostępowi do utworu dawne pokolenia moga nadal tłumaczyć i opisywać swój świat, odpowiadać na odwiecznie zadawane pytania. Z kolei współcześni badacze będą mogli zapoznać się z ich dorobkiem intelektualnym oraz na bieżąco komunikować i wymieniać się ze sobą wiedzą.

Stosownie do tego, co było zasygnalizowane na wstępie podrozdziału, należy przybliżyć ideę open access ${ }^{16}$. Koncepcja ta, na co wskazuje obcojęzyczna nazwa, nie jest pojęciem stworzonym na gruncie polskiej kultury prawnej, niemniej jednak szereg spośród

15 Zwyczajowo zawołanie konferencyjne nie jest szczegółową analizą problemu, a jedynie zarysowaniem ogólnie przyjętych wniosków $\mathrm{i}$ intuicji na dany temat

16 Choć interesuje nas pytanie, czy dzięki nowym regulacjom możliwe jest korzystanie na zasadach podobnych do open acces z utworów zwanych osieroconymi, dla porządku należy wskazać inne, bardziej ugruntowane w powszechnej świadomości, drogi korzystania z utworu chronionego majątkowymi prawami autorskimi. Po pierwsze, na gruncie polskiego prawa autorskiego możliwe jest korzystanie z utworu, w przypadku gdy od śmierci jego autora minęło najmniej 70 lat. Takie dzieło znajduje się już w zbiorze tzw. domeny publicznej, co oznacza m.in., że utwór nie podlega ograniczeniom wypływającym z praw majątkowych autora, gdyż te sa już wygasłe. Należy jednak pamiętać, iż w polskim systemie prawa autorskiego nie istnieje możliwość wyzbycia się autorskich praw osobistych (np. obowiązek zachowania integralności treści i formy utworu, 
wielu zasad, które się nań składaja, funkcjonuje w naszym obiegu prawnym. Wskazać jednak należy, że pojęcie to nie ma jednej definicji prawnej, a sam open access należy rozumieć jako system (czy systemy) reguł korzystania z utworów. Zasady tworzące open access nie stanowią też przedmiotu legislacji, a działają na gruncie funkcjonującego już prawa - przede wszystkim prawa autorskiego. Open access to także swoisty ruch społeczny i jako taki posiada wytyczne ujęte w „manifestach” — Berlińskiej Deklaracji o Otwartym Dostępie do Wiedzy Naukowej (Berliner Erklärung über offenen Zugang zu wissenschaftlichem Wissen) ogłoszonej w Instytucie Maxa Plancka w 2003 roku; Budapesztańskiej Inicjatywy Otwartego Dostępu z 2002 roku (Budapest Open Access Initiative) dotyczącej w szczególności literatury badawczej; Oświadczenie z Bethesdy o Publikowaniu w ramach Otwartego Dostępu (Bethesda Statement on Open Access Publishing). Najbardziej ideę open access oddaje fragment otwierający Inicjatywę Budapeszteńską:

An old tradition and a new technology have converged to make possible an unprecedented public good. The old tradition is the willingness of scientists and scholars to publish the fruits of their research in scholarly journals without payment, for the sake of inquiry and knowledge. The new technology is the internet. The public good they make possible is the world-wide electronic distribution of the peer-reviewed journal literature and completely free and unrestricted Access to it by all scientists, scholars, teachers, students, and other curious minds. ${ }^{17}$

(Budapest Open Access Initiative 2012)

Początkowo pojęcie open access używane było jedynie w kontekście czasopism naukowych. Jak zauważa Peter Suber, „literatura w otwartym dostępie (OD) ma postać cyfrowa, jest dostępna online, a także bezpłatna i wolna od większości ograniczeń prawnoautorskich i licencyjnych" (Suber 2014: 16). Oznacza to, że możliwe jest kopiowanie, wykorzystywanie, rozpowszechnianie, przenoszenie i pokazywanie pracy publicznie. Pojawia się możliwość tworzenia i rozpowszechniania utworów zależnych na wszelkich nośnikach cyfrowych, dla wszelkiego rodzaju odpowiedzialnego użycia, pod warunkiem oznaczenia utworu w sposób określony przez twórcę.

W książce Otwarty dostęp Peter Suber stwierdza, że istotą open access jest to, iż „może przyspieszyć badania w każdej dziedzinie i w każdym języku” (Suber 2014). Jeżeli biblioteka nie może sobie pozwolić na zakup danej publikacji, to ona znika z obiegu nauki światowej. Konstrukcja open access jest korzystna dla badaczy jako autorów (możliwość zacytowania, pogłębienia i wdrożenia wyników badań) i jako czytelników (uzyskanie dostępu

obowiązek oznaczenia autorstwa itp.), a ich czas trwania jest nieograniczony. Po drugie, w sytuacji, gdy autor żyje albo nie minęło jeszcze 70 lat od jego śmierci, możliwe jest bez zgody autora, względnie jego spadkobierców majątkowych praw autorskich, cytowanie (są normy dla cytatu) oraz inspirowanie (utwór inspirowany). Nie można natomiast bez zgody (autor, wydawca, spadkobierca) powielać ani tworzyć utworów zależnych (np. przekładów).

Oprócz OA w istnieją także struktury podobne, jak: Open Content, Creative Commons, Copy Left są to zjawiska odrębne, ale funkcjonujące w orbicie OA, a czasem także stanowiące, jak np. CC, jego treść i zasady dostępu.

Tłumaczenie własne:

Stara tradycja i nowe technologie złączyły się, aby urzeczywistnić bezprecedensowe dobro publiczne. Starą tradycją jest gotowość naukowców i badaczy do publikowania owoców swoich badań w czasopismach naukowych, bez zapłaty, dla dobra zdobywania i wiedzy. Nową technologia jest Internet. Dobrem publicznym, które realizują, jest światowa elektroniczna dystrybucja fachowej literatury całkowicie bezpłatnie i bez ograniczeń dostępu do niego przez wszystkich naukowców, badaczy, nauczycieli, studentów i innych ciekawych umysłów. 
do dużej ilości tekstów). Podążając tym tokiem myślenia, okazuje się, że sprzedawanie utworów może być niekorzystne, bo ogranicza liczbę odbiorców i zakres oddziaływania utworu, a tym samym staje się przeszkodą w osiaganiu celów zawodowych (np. zwiększaniu własnego Impact Factor).

Jak zauważa Peter Suber, open access niweluje wiele barier w dostępie do utworów jedną z nich jest cena. Inną są prawa autorskie. Natomiast „open access zwiększa użyteczność materiałów na dwa sposoby: umożliwia do niej dostęp większej liczbie zainteresowanych oraz daje mi prawo do ich swobodnego wykorzystywania i przetwarzania" (Suber 2014). Amerykański filozof podkreśla, że największe przeszkody we wdrożeniu otwartego dostępu mają charakter kulturowy, a nie techniczny, ekonomiczny czy prawno-autorski.

Co przemawia za open access? Jest kilka powodów, które uzasadniają takie rozwiązanie, m.in. finansowanie nauki ze środków publicznych — odpłatne udostępnianie publikacji naukowych jest podwójną sprzedażą wiedzy, która mogła zostać wytworzona np. z pieniędzy podatników. Idąc dalej tym tropem, trzeba zauważyć, że naukowcy, których utwory są udostępniane $\mathrm{w}$ ramach open access nie rezygnuja z tantiem, gdyż $\mathrm{i}$ tak nie otrzymuja wynagrodzenia za publikowane artykuły naukowe. Sa za to nagradzani przez uczelnie, otrzymuja granty badawcze, co pozwala im zgłębiać swoją dziedzinę i publikować artykuły specjalistyczne, które nie są podyktowane tylko i wyłącznie potrzebami rynku. Kolejną kwestia jest fakt, że open access to pełne poszanowanie praw autorskich (wola autora o takim sposobie udostępnienia tekstu) oraz nadal obowiązujący proces recenzowania artykułów w punktowanych czasopismach naukowych, który weryfikuje jakość udostępnianych wyników badań.

Open access może stać się przyczynkiem do refleksji, że być może konieczne jest powstanie nowej kultury badań: opartej na ciagłej cyrkulacji utworów, nieograniczonego krążenia tekstów, które dzięki temu zyskują nowe odczytania, a tym samym wzbogacają uniwersum nauki.

$\mathrm{Na}$ gruncie prawnym open access rozumiany jest jako swoista licencja, w której zgoda autora lub jej brak, a więc jego wola, przesądzają czy, kto i w jakim zakresie może korzystać z jego dorobku. W przypadku dzieł osieroconych autorzy zaginęli, znikając z horyzontu świadomości społecznej, nie wiadomo, gdzie są i czy żyja. Do niedawna obowiązujące przepisy zamykały szerszy dostęp do takich dzieł. Sytuacja ta sprawiała, że stworzone przez nich utwory mogły jedynie leżeć zamknięte w archiwach, istniejąc często tylko w świadomości bardzo nielicznych, przegrywających wyścig z czasem materii pojedynczych egzemplarzy. Nowe przepisy prawa autorskiego otwieraja dostęp do tych dzieł i tym samym umożliwiaja przywracanie ciagłości kultury. Warto, aby ta zamknięta część humanistyki stała się obecna w jej współczesnej wersji.

W przypadku utworów osieroconych autor nie wyraża woli (jego wola nie jest znana), więc może to powodować sytuację, w której pewne działania dokonują się wbrew jego (potencjalnej) woli. Można więc powiedzieć, że niejako uzurpujemy sobie prawo, iż dostęp do utworów osieroconych się nam należy. Dominuje w tej postawie „myślenie prometejskie" - aspekt dobra ogółu okazuje się w uzasadnionych przypadkach ważniejszy niż dobro indywidualne.

Znowelizowana w 2015 roku ustawa o prawie autorskim, która uwzględnia korzystanie w utworów osieroconych, pozwala podjąc decyzję za autora, umożliwia otwarcie sejfu, ale ma ograniczenia i wywołuje liczniejsze utrudnienia (w porównaniu z open access). 
Umożliwia wdrożenie misji, jaką jest uratowanie cząstek dziedzictwa kulturowego przed zapomnieniem i wydobycie go z niepamięci. Daje szansę, aby wygrać trudny wyścig z czasem i budzi świadomość, ile utworów być może się straciło, a teraz można — choć część z nich — odzyskać. Staje się rzecznikiem autorów nieżyjących, zaginionych itp., ale wspiera przede wszystkim współczesnych.

Powstanie ,instytucji” dzieł osieroconych i open access stanowią odpowiedź prawa na potrzeby społeczne wyrażone przez środowisko naukowe, na potrzebę zdobywania, rozwijania i agregowania wiedzy. Prawo tworzy ramy działania, reguły dostępu, ale to przede wszystkim środowisko artystyczne i naukowe staje się „,kołem zamachowym” tych zmian. W obu przypadkach, open access i dzieł osieroconych, działanie to nie jest nastawione na zysk materialny — istotny okazuje jest zysk społeczny i naukowy jako swoista misja.

\section{Bibliografia}

Archiwum Uniwersytetu Jagiellońskiego, prace doktorskie, sygn. WF II 505 - Stefania Tatarówna.

Barta Janusz, Markiewicz Ryszard (2011), Prawo autorskie i prawa pokrewne. Wprowadzenie, C.H. Beck, Warszawa.

Błeszyński Michał (2013), Dyrektywa poświecona utworom osieroconym pozostawia wiele do syczenia, http://serwisy.gazetaprawna.pl/prawo-autorskie/artykuly/699190,dyrektywa-poswieconautworom-osieroconym-pozostawia-wiele-do-zyczenia.html [dostęp: 10 lutego 2017].

Budapest Open Access Initiative (2012), Budapest, Hungary, http://www.budapestopenaccessinitiative.org/read [dostęp: 5 lipca 2017].

Damrosch David (2003), What is World Literature?, Princeton.

- (2010), Literatura światowa w dobie postkanonicznej i hiperkanonicznej, przeł. A. Tenczyńska [w:] Niewspótmierność. Perspektyny nowoczesnej komparatystyki. Antologia, red. T. Bilczewski, Wydawnictwo UJ, Kraków.

Druk sejmowy nr 3449. Uzasadnienie (2015), Rządowy projekt ustawy o zmianie ustawy o prawie autorskim i prawach pokrewnych oraz ustawy o grach hazardowych, http:// www.sejm.gov.pl/sejm7.nsf/druk.xsp?nr=3449 [dostęp 10 lutego 2017].

Dyrektywa Parlamentu Europejskiego i Rady 2012/28/UE z 25 października 2012 r. w sprawie niektórych dozwolonych sposobów korzystania z utworów osieroconych.

Instytut Informacji Naukowej i Bibliotekoznawstwa Uniwersytetu Wrocławskiego (2016), Zaproszenie na konferencję Kultura ksią̇ki w bumanistyce wspótczesnej. Konferencja naukowa z okazji Jubileuszu 60-lecia Instytutu Informacji Nankowej i Bibliotekoznawstwa, http://www.ibi. uni.wroc.pl/konferencja [dostęp: 12 lutego 2017]. 
Jarmuszkiewicz Anna (2012), Kanon i tradycja w perspektywie literatury światowej [w:] Tradycja wspótcæésnie: repetycja cঞy innowacja?, red. A. Jarmuszkiewicz, J. Tabaszewska, Wydawnictwo UJ, Kraków.

Kulczykowski Mariusz (2004), Żydzi - studenci Uniwersytetu Jagiellońskiego w Drugiej Ržeczypospolitej (1918-1939), PAU, Kraków.

Pajestka Jozef (1991), Polskie frustracje i wyzwania: przesłanki postępu cywilizacyjnego, Polska Oficyna Wydawnicza BGW, Warszawa.

Rozporządzeniu Ministra Kultury i Dziedzictwa Narodowego z 23 października 2015 r. w sprawie wykazu źródeł, których sprawdzenie jest wymagane w ramach starannych poszukiwań uprawnionych do utworów i przedmiotów praw pokrewnych, które mogą być uznane za osierocone, oraz sposobu dokumentowania informacji o wynikach starannych poszukiwań, Dz. U. poz. 1258.

Suber Peter (2014), Otwarty dostęp, przeł. R. Bogacewicz, M. Chojnowski, Wydawnictwo UW, Warszawa.

Szczepańska Barbara (2008), Dzieła osierocone. Palace problemy, propozycje rozwiazań, Biblioteki bez papieru, Nr 3 (94), http://www.ebib.pl/2008/94/a.php?szczepanska [dostęp: 10 lutego 2017].

Tatarówna Stefania (1906a), Stowacki i Nietzssche. (Król-Duch a Nadczłowiek), „Pamiętnik Literacki”, z. 3 .

- (1906b), Stowacki i Nietssche. (Król-Duch a Nadç̨łowiek): II, III, „Pamiętnik Literacki”, z. 4.

Ustawa o prawie autorskim i prawach pokrewnych. Komentarz (2011), red. J. Barta, R. Markiewicz, C.H. Beck, Warszawa.

Ustawa z 11 września 2015 r. o zmianie ustawy o prawie autorskim i prawach pokrewnych oraz ustawy o grach hazardowych, Dz.U. 2015 poz. 1639.

Ustawa z 4 lutego 1994 r. o prawie autorskim i prawach pokrewnych, Dz.U. 1994 nr 24 poz. 83.

Vetulani-Cęgiel Agnieszka (2013), Wptyw lobbingu na politykę Unii Europejskiej w zakresie dziet osieroconych [w:] Dzieła osierocone, red. D. Sokołowska, Wydawnictwo WSUS, Poznań. 